\title{
Recombinant Inhibin A
}

National Cancer Institute

\section{Source}

National Cancer Institute. Recombinant Inhibin A. NCI Thesaurus. Code C1631.

A recombinant therapeutic agent which is chemically identical to or similar to an endogenous glycoprotein which inhibits pituitary production of follicle-stimulating hormone (FSH). Produced and secreted by the testis or ovarian follicle, endogenous inhibin A contributes to the control of gametogenesis, embryonic and fetal development, and hematopoiesis and enhances LH-stimulated androgen secretion by human thecal cells. $(\mathrm{NCl04})$ 